\title{
Presidential Threshold Anomaly in Indonesian Government System: Parlementer Reduction in Indonesian Presidential System
}

\author{
Dwi Rianisa Mausili ${ }^{1}$ \\ University of Indonesia - Indonesia
}

\begin{abstract}
The government system running in Indonesia is a combination of presidential systems and parliamentary systems. Based on the 1945 Constitution, Indonesia adheres to a presidential system, but Indonesia, in implementing there are many parts of the parliamentary system that are included in the Indonesian presidential system. The strengthen presidential system effort is still carried out, one of which is the rule of threshold number in Article 222 of Law Number 7 of 2017 about General Elections. However, the presidential threshold (threshold number) is assumed that it will be strengthen the presidential system in the Indonesian government system and experience anomalies, irrational and irrelevant. With the presidential threshold, political parties can nominate the presidents and the vice by provision of political party or joint political party having $20 \%$ of seats or $25 \%$ of nationally legitimate votes in the previous legislative elections. With the existence of the presidential threshold, it will give a positive value, namely First, directing political parties to coalition with other parties. Secondly, political parties after the general election will form two shafts. Those are the bearer axis and the opposition axis. Third, the presidential threshold comes up with a new understanding that is political parties only bearers, so in the 2019 simultaneous elections there will be elected strong president and vice figures regardless of the small voice of the party that carries them. This paper uses critical discourse analysis toward the opportunities and realization problem challenges of the threshold presidential in Indonesia. The purpose of this writing is the first, how the threshold presidential relevance in Indonesia is, second, how to create an ideal government system thought of the threshold presidential system to reduce parliamentary in the Indonesian presidential system.
\end{abstract}

Keywords: Presidential Threshold, Parliament, Ideal Government System

\footnotetext{
1 Dwi Rianisa Mausili is a Master Student at University of Indonesia, Indonesia. E-mail: dwirianisamausili@gmail.com
} 
Anomali Presidential Threshold dalam Sistem Pemerintahan Indonesia: Reduksi Parlementer dalam Sistem Presdensil Indonesia

\section{Dwi Rianisa Mausili}

\section{Pendahuluan}

Dalam konteks pemilihan umum serentak, syarat kontestasi sistem ambang batas atau presidential threshold dalam pencalonan Presiden dan Wakil Presiden menjadi isu krusial bagi partai politik, pemerintah, akademisi maupun masyarakat. Sistem presidential threshold yang juga diajukan permohonan gugatan uji materi. Upaya dalam memperkuat sistem presidensial terus dilakukan salah satunya dengan adanya aturan angka ambang batas dalam pasal 222 Undang-undang Nomor 7 tahun 2017 tentang Pemilihan Umum. Akan tetapi presidential threshold (angka ambang batas) yang dianggap akan memperkuat sistem presidensial perjalanannya dalam sistem pemerintahan Indonesia mengalami anomali, irasional dan tidak relevan. Dengan adanya presidential threshold, partai politik dapat mencalonkan presiden dan wakil presiden dengan ketentuan partai politik atau gabungan partai politik tersebut memiliki dua puluh persen kursi atau dua puluh lima persen suara sah nasional di pemilihan legislatif sebelumnya.

Pasal 9 Undang-Undang Nomor 42 Tahun 2008 tentang Pemilihan Umum Presiden dan Wakil Presiden menyatakan bahwa: "Pasangan calon diusulkan oleh partai politik atau gabungan partai politik peserta pemilu yang memenuhi persyaratan perolehan kursi paling sedikit 20\% (dua puluh persen) dari jumlah kursi DPR atau memperoleh 25\% (dua puluh lima) persen dari suara sah nasional dalam pemilu anggota DPR, sebelum pelaksanaan pemilu presiden dan wakil presiden" ditolak dengan menegaskan bahwa ketentuan pencalonan presiden dan wakil presiden atas dasar delegasi kekuasaan yang diberikan oleh UUD 1945 kepada pembentuk undang-undang untuk mengatur setiap ketentuan pemilu dalam UU pemilu sepanjang tidak melanggar moralitas, rasionalitas, dan ketidakadilan yang tidak dapat ditoleransi.

Dalam ilmu ketatanegaraan, terdapat beberapa ciri-ciri khusus suatu negara dapat dikatakan menganut sistem presidensial yaitu pertama, presiden adalah Kepala Negara dan Kepala Pemerintahan, kedua, presiden tidak dipilih oleh parlemen, tetapi langsung dipilih oleh rakyat (popular elected), ketiga, presiden bukan bagian dari parlemen dan tidak dapat diberhentikan oleh parlemen kecuali melalui proses pemakzulan (impeachment), terakhir, presiden tidak dapat membubarkan oleh parlemen. 
Presidential threshold awalnya dipergunakan untuk melihat tingkat kompetisi partai untuk menduduki kursi di daerah pemilihan dalam sistem pemilu proporsional. Konsep ini mengaitkan besaran daerah pemilihan (district magnitude) dan formula perolehan kursi partai dengan metode kuota. Hal ini mengindikasikan bahwa semakin besar besaran daerah pemilihan, maka semakin kecil persentase perolehan suara untuk mendapatkan kursi, sebaliknya semakin kecil besaran daerah pemilihan, maka semakin besar persentase perolehan suara untuk mendapatkan kursi.

Adanya aturan presidential threshold, tentu tidak ada peluang untuk calon presiden dan wakil presiden Independent (non partai) di Indonesia yang ingin berpartisipasi dalam pemilihan umum, hanya partai dan gabungan partai yang berpeluang mengusulkan pasangan presiden dan wakil presiden. Meskipun presidential threshold bertujuan untuk mengusulkan calon presiden dan calon wakil presiden yang berkualitas, namun presidential threshold belum bisa dilaksanakan di Indonesia dengan baik, mengingat banyaknya partai politik di dengan suara dan kursi yang bervariasi. Sehingga partai dengan jumlah suara kursi yang kecil tidak dapat mengusulkan calon presiden dan calon wakil presiden. Jumlah partai politik yang terlalu banyak merupakan salah satu faktor penyumbang tidak efektifnya sistem pemerintahan di Indonesia. Banyaknya partai politik yang ikut dalam pemilu menyebabkan koalisi yang dibangun untuk mencalonkan presiden dan wakil presiden terlalu "gemuk" karena melibatkan banyak parpol. Gemuknya koalisi ini mengakibatkan pemerintahan hasil koalisi tidak dapat berjalan efektif karena harus mempertimbangkan banyak kepentingan.

Dari penjabaran di atas, maka penelitian ini mengamati tentang: pertama, relevansi presidential threshold di Indonesia, kedua, cara mewujudkan sistem pemerintahan ideal yang lahir dari sistem presidential threshold untuk mereduksi parlementer dalam sistem presidensil Indonesia. Sehingga hasil penulisan ini dapat menjabarkan tujuan penelitian, membentuk lembaga yang ideal dan dibutuhkan guna mewujudkan keberhasilan visi indonesia 2045.

\section{Tinjauan Literatur}

Dalam Bahasa hukum tidak dijelaskan terminologi dari istilah Presidential Threshold. Kamus besar Bahasa inggris dan Bahasa Indonesia dapat membantu menerjemahkan istilah presidential threshold. Istilah presidentia/berasal dari kata president, dimana kamus Black Law memberikan definisi yaitu kepala eksekutif dari suatu bangsa khususnya pada pemerintahan yang berbentuk demokrasi. Lebih lanjut, threshold berasal dari Bahasa Inggris yaitu ambang pintu atau ambang batas, dimana Kamus Besar Bahasa Indonesia mendefinisikan ambang batas sebagai tingkatan batas yang masih dapat diterima atau ditoleransi (Raditya, 2013: 4). 
Pamungkas (2009: 19), presidential threshold adalah pengaturan tingkat ambang batas dukungan dari DPR, baik dalam bentuk jumlah perolehan suara (ballot) atau jumlah perolehan kursi (seat) yang harus diperoleh partai politik peserta pemilu agar dapat mencalonkan Presiden dari partai politik tersebut atau dengan gabungan partai politik. Wijaya (2014: 564), presidential threshold terkait dengan kebijakan ambang batas parlemen atau parlementary threshold yang menggantikan electoral threshold. Presidential threshold ini menjadi salah satu cara penguatan sistem presidensial melalui penyederhanaan partai politik. Tujuannya menciptakan pemerintahan yang stabil dan tidak menyebabkan pemerintahan yang berjalan mengalami kesulitan di dalam mengambil kebijakan dengan lembaga legislatif.

Sebagai suatu kebiasaan umum dalam pemilihan Presiden Republik Indonesia Presidential Threshold merupakan istilah yang sering dikorelasikan dengan Pasal 9 Undang-Undang Nomor 42 Tahun 2008 Tentang Pemilihan Umum Presiden dan Wakil Presiden (UU Pilpres). Pasal 9 UU Pilpres tersebut tidak menegaskan terminologi presidential threshold secara eksplisit namun telah menjadi kebiasaan umum dalam pemilu di Indonesia mengartikan bahwa presidential threshold atau ambang batas yaitu syarat bagi calon presiden dan wakil presiden untuk maju dalam pemilihan umum. Syarat tersebut yakni perolehan kursi paling sedikit 20 persen dari jumlah kursi DPR-RI atau memperoleh 25 persen dari suara sah nasional dalam pemilu anggota DPRRI, sebelum pelaksanaan Pemilu Presiden dan Wakil Presiden.

Secara teoritis, threshold merupakan tingkat minimal dukungan yang harus diperoleh agar dapat menempatkan perwakilan dan pada umumnya dikembangkan pada negara-negara yang menggunakan sistem pemilu perwakilan proporsional (Gusti, 2013). Pemilihan presiden ditentukan dalam Pasal 159 ayat (2) dan ayat (3) UU No. 42 Tahun 2008 menggunakan sistem pluralitas/mayoritas dengan varian sistem dua putaran (two round system) dikombinasikan dengan syarat distribusi persebaran suara berdasarkan Pasal 159 ayat (4) dan ayat (5) UU No. 42 Tahun 2008 berdasarkan prinsip tersebut presidential threshold menjadi tidak sesuai dengan sistem yang digunakan dalam pemilihan presiden dan wakil presiden.

Presidential Threshold selanjutnya dapat dimaknai sebagai rule of game alat yang menentukan partai politik mana yang bisa mengusung calon pasangan presiden dan wakil presiden dalam pemilu. Ambang batas atau presidential threshold ini banyak dikritik oleh beberapa pihak salah satunya ialah partai-partai kecil yang perolehan suaranya tidak mencukupi ketentuan presidential threshold, partai-partai kecil menganggap mekanisme ini bertentangan dengan hak konstitusional warga negara walau ada opsi bagi partai yang suaranya kurang mencukupi ketentuan Presidential Threshold untuk bergabung dengan partai politik lain dengan menyatukan ideologi dan cita- cita kebangsaan yang diusung. 
Partai politik berperan penting untuk turut andil dalam proses pelaksanaan demokrasi. Inilah yang diamanatkan dalam pasal 6A ayat (2) Undang-Undang Dasar 1945. Jika melihat ketentuan pasal tersebut, maka sistem presidential threshold menjadi tidak memiliki relevansi lagi atau sudah kehilangan urgensinya dengan adanya pemilu serentak berdasarkan Putusan MK Nomor 14/PUU-XI/2013. Tentulah suatu hal yang kontradiktif apabila Mahkamah Konstitusi mengeluarkan putusan yang tidak mengacu pada Undang-Undang Dasar. Sementara diberlakukannya sistem presidential threshold dalam pemilu presiden sebagai penguatan sistem presidensil yang dianut dalam Undang-Undang Dasar Negera Republik Indonesia Tahun 1945.

\section{Metodologi}

Penelitian ini menggunakan metode analisis wacana kritis dari Teun A. van Dijk, Fairclough, dan Wodak (dalam Eriyanto, 2001:7) untuk meninjau wacana diberlakukannya sistem presidential threshold dengan melihat beberapa aspek: pertama, aspek Tindakan dalam wacana yang dipahami sebagai sesuatu bentuk ekspresi sadar dan terkontrol. Kedua, Konteks dari wacana, seperti latar, situasi, peristiwa, dan kondisi yang harus ditafsirkan dalam situasi dan kondisi yang khusus. Ketiga, Historis wacana dalam konteks sosial yang diproduksi dalam konteks tertentu dan tidak dapat dimengerti tanpa menyertakan konteks yang menyertainya. Keempat, wacana yang muncul, dalam bentuk teks, tidak dipandang sebagai sesuatu yang alamiah, wajar dan netral, tetapi merupakan bentuk pertarungan kekuasaan. Kelima, melihat unsur ideologi dalam wacana yang dibangun oleh kelompok yang dominan.

Teknik pengumpulan data menggunakan studi pustaka dan penelusuran data online. Uji keabsahan data dalam penelitian kualitatif meliputi beberapa pengujian. Peneliti menggunakan Uji Kredibilitas Data atau uji kepercayaan terhadap hasil penelitian.

Teknik analisis data dalam penelitian ini meliputi: pertama, Data Collection merupakan kegiatan pengumpulan data-data. Kedua, Data Reduction merupakan kegiatan mereduksi data-data yang diperoleh, menggolongkan, mengarahkan, membuang data yang tidak diperlukan dan mengorganisasi data. Ketiga, Data display merupakan kegiatan memperlihatkan data yang diperoleh setelah direduksi terlebih dahulu. Keempat, Conclusing drawing atau verification merupakan kegiatan membuat kesimpulan dengan menggambarkan, memverifikasi dan menyajikan datadata yang diperoleh dalam bentuk kalimat. 


\section{Hasil Analisis}

\subsection{Sistem Presidensial dan Relevansinya di Indonesia}

Sistem pemerintahan presidensial dicirikan oleh pemilihan kepala negara secara langsung oleh rakyat, bukan dipilih oleh parlemen seperti yang berlaku pada sistem parlementer. Presiden bukan bagian dari parlemen dan tidak bisa diberhentikan oleh parlemen, kecuali melalui proses pemakzulan (impeachment) dan Presiden tidak dapat membubarkan parlemen sebagaimana halnya sistem parlementer yang memberi hak kepada kepala negara untuk membubarkan parlemen (Haris, 2011: 2). Dalam sistem pemerintahan presidensial, fokus kekuasaan terpusat pada lembaga eksekutif, sehingga yang menjadi kepala pemerintahan adalah presiden (yang merangkap sebagai kepala negara), memiliki masa jabatan tetap sesuai dengan periodisasi jabatan presiden di masing-masing negara. Presiden tidak bertanggungjawab kepada parlemen, sehingga parlemen sesungguhnya tidak memiliki otoritas untuk menurunkan presiden dalam masa jabatannya.

Pada dasarnya, karakteristik utama sistem presidensial secara umum merupakan kebalikan dari karakteristik sistem parlementer. Dalam karakteristik politik presidensial, basis legitimasi presiden bersumber dari rakyat. Karena itu, sistem pemerintahan presidensial ditandai dengan penerapan sistem pemilihan presiden dan wakil presiden secara langsung oleh rakyat dengan masa jabatan yang tetap (fixed term). Implikasi legitimasi politik presiden yang bersumber dari rakyat melalui pemilihan secara langsung adalah presiden tidak bertanggungjawab kepada lembaga parlemen, tetapi langsung bertanggungjawab kepada rakyat. Konsekuensi masa jabatan yang bersifat tetap adalah presiden yang dipilih secara langsung tidak mudah dijatuhkan parlemen (lembaga legislatif). Institusi parlemen dalam sistem presidensial juga tetap, sehingga tidak dapat dibubarkan presiden. Konsekuensinya, proses pemakzulan presiden dan wakil presiden dari jabatannya hanya bisa dilakukan melalui proses peradilan (Lijphart, 1995: 4-6).

Berangkat dari basis teoritis penerapan konsep presidensialisme, ide utama sistem presidensial (presidensialisme) pada dasarnya adalah meletakkan presiden sebagai poros kekuasaan pemerintahan, tetapi penerapannya tetap dalam kendali rakyat dalam kerangka demokrasi. Dalam penerapannya, pemilihan presiden secara langsung ditujukan untuk mendapatkan pemimpin pemerintahan dan negara yang memiliki legitimasi yang kuat karena dipilih dan didukung secara langsung oleh mayoritas rakyat Indonesia. Pemilu presiden dan wakil presiden 2004 menghasilkan pemerintahan yang memiliki legitimasi yang kuat. Namun persoalan lain yang muncul adalah pemerintah terpilih tidak mampu menyelesaikan permasalahan-permasalahan yang sedang dihadapi oleh bangsa. Ketidakmampuan pemerintah mengimplementasikan kebijakan-kebijakan 
publik disebabkan karena pemilu presiden secara langsung tidak menghasilkan pemerintahan yang efektif, kuat dan stabil.

Menurut Syamsuddin Haris, dkk (2015:3), setidaknya ada tiga alasan mengapa kombinasi sistem presidensial dan sistem multipartai cenderung bermasalah, yaitu: (1) Sistem presidensial berbasis multipartai cenderung mengakibatkan kebuntuan hubungan eksekutif dan legislatif sehingga kerja pemerintahan menjadi tidak efektif; (2) Sistem multipartai cenderung menciptakan polarisasi ideologis daripada sistem dua-partai; (3) Kombinasi kedua sistem tersebut juga berimplikasi pada sulitnya membentuk koalisi antarpartai dalam sistem presidensial; Permasalahan yang terjadi dalam penentuan koalisi pilpres untuk mengusung calon presiden dan wakil presiden ada pasca penetapan kursi legislatif yang fragmentatif. Lobby politik terjadi dimana-mana, sifat pragmatis, dan singkat menjadi kerikil tajam yang juga kerap terjadi dimanapun, termasuk di Indonesia. Akibatnya, pemerintah yang terpilih menjadi tersandera baik oleh kekuatan pendukungnya sendiri dan juga oleh pihak oposisi.

Selain itu, sistem kepartaian sangat berpengaruh terhadap sistem presidensial. Hal ini tampak pada Pemerintahan di bawah kepemimpinan Presiden era reformasi yang sangat tidak efektif dalam mengimplementasikan program-program yang dihasilkan di tengah-tengah masyarakat. Tidak efektifnya pemerintahan saat itu disebabkan karena hubungan antara lembaga kepresidenan dan lembaga parlemen tidak baik sehingga programprogram pemerintah yang harus mendapatkan persetujuan dari parlemen mendapatkan resistensi dari DPR, bahkan ditolak oleh DPR. Dengan demikian program atau rencana kerja pemerintah tidak dapat berjalan dengan sebagaimana mestinya. Problem efektivitas pemerintah yang dialami oleh Indonesia saat ini juga banyak dialami negara-negara lain yang menganut sistem pemerintahan presidensial.

Mainwaring (dalam Partono, 2010: 3) berpendapat bahwa hanya empat negara penganut sistem presidensial yang berhasil dalam menciptakan pemerintah yang efektif dan stabil yaitu Amerika Serikat, Costa Rica, Columbia, dan Venezuela. Selain negara yang menganut sistem presidensial, mayoritas negara-negara yang menganut sistem parlementer juga sukses dalam menjaga stabilitas dan efektivitas pemerintahan antara lain; Australia, Austria, Belgia, Kanada, Denmark, Jerman, Irlandia, Belanda, Inggris, Selandia Baru, Italia dan sebagainya. Kombinasi antara sistem presidensial dan sistem multi partai yang dipraktikkan di Indonesia tidak menghasilkan pemerintahan yang efektif dan stabil. Sistem pemerintahan memiliki korelasi langsung terhadap efektivitas pemerintahan, karena terdapat bukti kalau kedua sistem pemerintahan mampu menciptakan pemerintahan yang efektif. Meskipun tidak ada hubungan yang langsung antara sistem pemerintahan dengan efektivitas pemerintah, akan tetapi ada beberapa hal di dalam sistem presidensial yang mempengaruhi efektivitas pemerintah. Dari segi menjaga 
stabilitas politik dan pemerintahan, Indonesia memiliki pengalaman yang berharga dan mampu menjawab bahwa sistem presidensial ternyata mampu menghasilkan stabilitas politik dan pemerintahan yang lebih baik jika dibandingkan dengan sistem parlemen.

Salah satu alasan Amerika dengan sistem presidensial mampu menghasilkan pemerintah yang efektif karena ditopang oleh sistem dwipartai. Sedangkan Indonesia mempraktikkan sistem presidensial dan sistem multipartai. Ada beberapa alasan mengapa sistem presidensial dan sistem multipartai kurang berhasil di dalam menciptakan pemerintahan yang efektif dan stabil dibandingkan dengan sistem parlementer yang dikombinasikan dengan sistem dua partai yaitu pertama, pemilihan presiden dan parlemen diselenggarakan secara terpisah maka kemungkinan presiden yang terpilih adalah presiden yang tidak mendapatkan dukungan mayoritas di parlemen. Semakin besar dukungan parlemen kepada presiden maka implementasi kebijakan publik oleh pemerintah akan semakin efektif. Sebaliknya semakin kecil dukungan parlemen maka efektivitas pemerintah di dalam mengimplementasikan kebijakan-kebijakan akan semakin berkurang.

Kedua, personal presiden, termasuk kepribadian dan kapasitas merupakan salah satu faktor yang penting. Di dalam sebuah situasi yang sulit seperti keadaan krisis ekonomi saat ini presiden dihadapkan pada pekerjaan yang sangat banyak dan rumit. Oleh karena itu presiden juga dituntut memiliki kapasitas yang baik untuk menangani berbagai permasalahan yang sedang dihadapi. Selain dituntut untuk memiliki kapasitas dalam menangani permasalahan bangsa, presiden membutuhkan dukungan (support) dari parlemen, sehingga presiden juga dituntut untuk memiliki kemampuan berkomunikasi dan lobby yang baik dengan parlemen. salah satu faktor kurang efektifnya pemerintahan saat ini disebabkan kelemahan di dalam mengelola dukungan dari koalisi partai politik yang mendukung pemerintah dan lemahnya/ketidakmampuan presiden melakukan komunikasi dan lobby politik dengan parlemen.

Ketiga, di dalam sebuah sistem presidensial dan multipartai membangun koalisi partai politik untuk memenangkan pemilu adalah hal yang sangat wajar dan umum terjadi. Koalisi partai politik terjadi karena untuk mendapatkan dukungan mayoritas dari parlemen merupakan sesuatu yang sangat sulit. Namun masalahnya adalah koalisi yang dibangun di dalam sistem presidensial, khususnya di Indonesia, tidak bersifat mengikat dan permanen. Partai politik yang tergabung di dalam sebuah koalisi mendukung pemerintah bisa saja menarik dukungannya. ${ }^{1}$ Tidak adanya jaminan bahwa koalisi terikat untuk mendukung pemerintah sampai dengan berakhirnya masa kerja presiden. Partai-partai politik yang tergabung di dalam koalisi cenderung mengambil keuntungan dari pemerintah. Jika kebijakan atau program yang diambil oleh pemerintah tidak populer maka partai politik cenderung menjadi 
oposisi yang selalu mengkritik secara tajam program yang dilakukan oleh presiden.

Selain itu, koalisi partai politik yang dibangun untuk mendukung calon presiden tidak mencerminkan dan menjamin dukungan semua anggota parlemen dari masing-masing partai politik yang ada di dalam koalisi kepada presiden. Partai politik tidak mampu melakukan kontrol terhadap para anggota-anggotanya di parlemen untuk selalu mendukung pemerintah. Di dalam sistem parlementer koalisi partai politik lebih bersifat permanen dan disiplin. Koalisi partai politik dibangun atas dasar parlemen. Anggota parlemen dari koalisi partai politik pendukung pemerintah yang tidak mendukung kebijakan pemerintah akan dikeluarkan dari parlemen. Selain ancaman dikeluarkan dari keanggotaan parlemen oleh partai politiknya, jika anggota tidak mendukung program-program pemerintah agar berhasil perolehan kursi partai mereka akan terancam pada pemilu berikutnya. Sehingga suksesnya pemerintah terbentuk juga mempengaruhi citra partai politik pendukungnya.

Jika koalisi parpol dalam sistem parlementer dibangun setelah pemilu, koalisi parpol dalam sistem presidensial dibangun sebelum pemilu presiden dilaksanakan. Akibatnya beberapa partai politik mendukung di dalam pencalonan akan tetapi tidak mendukung ketika calon tersebut terpilih. Hal ini disebabkan, misalnya, tidak terwakilinya partai tersebut di kabinet. Kalaupun terdapat perwakilan partai di kabinet, partai politik tersebut tidak bertanggungjawab atas kebijakan-kebijakan pemerintah. Keempat adalah lemahnya penegakan fatsoen politik politisi yang ada di eksekutif maupun parlemen. Tidak bisa dipungkiri bahwa terdapat beberapa politisi di parlemen yang tidak mengindahkan etika dalam berpolitik sehingga anggota DPR terkesan ingin mencari popularitas di hadapan publik dengan melakukan berbagai kritikan-kritikan terhadap semua kebijakan pemerintah, tidak peduli apakah program dan kebijakan tersebut baik atau tidak bagi masyarakat.

Perilaku inilah yang menyebabkan pengambilan keputusan di parlemen sulit untuk dicapai secara efektif. Sebaliknya beberapa menteri di kabinet lebih menunjukkan loyalitas kepada ketua partainya dibandingkan dengan kepada presiden. Atau bahkan para pembantu presiden tersebut lebih disibukkan dengan kegiatan konsolidasi internal partai politik dibandingkan dengan membantu presiden mengimplementasikan program-program pemerintah. Tidak bisa dipungkiri kabinet hasil koalisi ini sering terjadi conflict of interest karena pejabat partai politik yang ditunjuk sebagai menteri tidak mengundurkan diri dari jabatan di partai politik.

\subsection{Mewujudkan sistem pemerintahan melalui sistem presidential threshold}

Tujuan utama penataan sistem politik Indonesia, untuk menciptakan pemerintahan yang efektif dan stabil, maka ada beberapa jalan keluar yang patut dipertimbangkan oleh para pembuat kebijakan. Beberapa alternatif untuk mewujudkan presidential threshold yaitu pertama, mengubah sistem 
pemerintahan. Pilihan ini dapat dikatakan sulit, bahkan dikatakan mustahil untuk dilakukan. Selain pengalaman traumatis yang pernah dialami Indonesia pada masa demokrasi parlementer, UUD 1945 secara tegas mengamanatkan bahwa sistem pemerintahan Indonesia adalah presidensial. Tidak mudah untuk melakukan amandemen terhadap UUD, akan memerlukan perdebatan yang panjang dan pasti akan mendapatkan resistensi yang sangat besar sehingga pilihan itu sangat tidak realistis untuk dipilih.

Kedua, menyederhanakan sistem kepartaian. Contoh negara yang mengimplementasikan sistem presidensial yang sukses adalah Amerika dimana sistem presidensial di dukung oleh sistem dwi partai. Kalau bangsa Indonesia ingin berkiblat kepada Amerika di dalam menata sistem politiknya maka sistem multi partai haruslah diubah menjadi sistem dwi partai. Tawaran solusi ini sepertinya juga sulit untuk direalisasikan karena akan melawan arus demokrasi. Masyarakat Indonesia yang sifatnya plural tidak akan bisa direpresentasikan oleh dua partai politik saja. Ketiga, mengurangi jumlah partai politik. Partai politik yang terlalu banyak juga merupakan salah satu faktor penyumbang tidak efektifnya sistem pemerintah di Indonesia. Banyaknya partai politik yang ikut dalam pemilu menyebabkan koalisi yang dibangun untuk mencalonkan presiden dan wakil presiden terlalu "gemuk" karena melibatkan banyak parpol. Gemuknya koalisi ini mengakibatkan pemerintahan hasil koalisi tidak dapat berjalan efektif karena harus mempertimbangkan banyak kepentingan. Jika saja partai politik yang ikut serta pemilu tidak banyak, maka koalisi parpol yang dibangun juga tidak akan menjadi "gemuk". Presiden terpilih idealnya berasal dari koalisi yang sekurangkurangnya mendapatkan dukungan parlemen 50\% dari jumlah kursi DPR dan jumlah partai yang ikut berkoalisi tidak banyak, cukup dua atau tiga partai saja.

Alternatif solusi ini lebih moderat, karena masih mempertahankan sistem presidensial dan sistem multi partai. Hanya saja jumlah partai di Indonesia yang terlalu banyak ini perlu disederhanakan. Penyederhanaan partai politik sebenarnya sudah dilakukan sejak pemilu 1999 dengan mengimplementasikan ambang batas bagi partai politik untuk ikut serta dalam pemilu berikutnya (Electoral Threshold) dan ambang batas bagi partai politik untuk mengirimkan wakilnya di parlemen (Parliamentary Threshold) - akan diberlakukan pada pemilu 2009. Alternatif mengurangi jumlah partai dan dibarengi dengan koalisi partai yang disiplin dan mengikat, adalah solusi yang paling memungkinkan dalam konteks Indonesia. Berapa jumlah partai politik yang efektif dan ideal bagi bangsa Indonesia yang perlu didiskusikan lebih lanjut. Beberapa pengamat mengatakan bahwa masyarakat Indonesia cukup diwakili oleh 5 partai politik saja. Sedangkan berdasarkan survei yang pernah diselenggarakan oleh salah satu lembaga survei jumlah partai politik yang dikehendaki oleh publik adalah 5-7 partai. Dengan dilakukannya mengurangi jumlah partai politik, APBN akan berkurang. Partai yang ada juga harus 
memperbaiki rekrutmen anggota partai sehingga setiap kader partai tersebut akan berkualitas.

Keempat, menyelenggarakan pemilihan presiden dan legislatif secara bersama-sama (Concurrent Elections akan menciptakan pemerintahan yang efektif. Dengan concurrent elections presiden terpilih akan mendapatkan legitimasi yang kuat dari rakyat dan mendapatkan dukungan yang kuat dari parlemen. Dalam negara yang menganggap pemilihan presiden lebih penting dibandingkan pemilihan legislatif, pemilih akan cenderung memilih partai politik yang mencalonkan presiden yang didukungnya. Akibatnya partai politik yang mendukung calon presiden terpilih akan memiliki peluang besar untuk memenangkan pemilu legislatif. Dengan demikian mayoritas anggota parlemen berasal dari partai tersebut.

\section{Kesimpulan dan Rekomendasi}

Pemilihan umum serentak merupakan cara untuk mengembangkan konsep demokrasi di Indonesia. Ketika pemilihan umum berlangsung, suara rakyat disampaikan melalui proses pemungutan suara. Masyarakat dilibatkan dalam proses penting suksesi kepemimpinan secara periodik. Prinsip supremasi hukum melekat dalam budaya demokrasi. Hukum berdaulat secara penuh dalam proses pemerintahan. Selain keterlibatan masyarakat dan prinsip supremasi hukum, kebebasan juga merupakan unsur mendasar dari proses demokrasi. Rakyat memiliki kebebasan untuk berkumpul, berpendapat, serta kebebasan berserikat yang diaktualisasikan dalam suatu partai politik. Secara terstruktur, partai politik berkembang mengikuti perkembangan atau proses transisi dalam sistem politik.

Tentu pola sistem presidential threshold akan berdampak bagi keberadaan organisasi partai politik. Apabila sistem presidential threshold masih diberlakukan, maka sebelum penyelenggaraan pemilihan umum serentak, idealnya telah ditentukan partai-partai politik yang mana saja yang menjadi peserta pemilu. Sebaliknya, apabila sistem presidential threshold dihapuskan, maka secara otomatis setiap partai politik memiliki tiket untuk mengajukan pasangan presiden dan wakil presiden tanpa harus berkoalisi. Artinya untuk mewujudkan konsep efektivitas sistem presidensial dengan multipartai moderat (sederhana) dalam pemilihan umum secara serentak sulit tercapai.

Oleh karena itu, hasil penelitian ini dapat mendorong beberapa rekomendasi yaitu perlu adanya pengurangan jumlah partai, penguatan ideologi partai dan sistem kader partai politik menjadi hal yang penting pada saat penyeleksian partai politik peserta pemilihan umum, sehingga terjadinya partai politik peserta pemilihan umum kedepannya benar-benar partai yang kuat secara ideologi dan memiliki basis massa yang besar agar melahirkan pemimpin yang kuat dari segala aspek. Juga perlu adanya pembentukan 
Lembaga Pengawas Partai Politik agar lebih terarah dalam sistem perekrutan kader partai politik, ideologi partai politik yang dianut, serta penyeleksian partai pemilu pantas menjadi peserta pemilihan umum.

VI. Referensi

Agus Adhari. (2019). Eksistensi Presidential Threshold Pada Pemilihan Umum Serentak. (ebook), hlm. 3.

Denny, Indrayana. (2008). Negara Antara Ada dan Tiada Reformasi Hukum Ketatanegaraan. Jakarta: Kompas.

Eriyanto. (2001). Analisis Wacana: Pengantar Analisis Teks Media. Yogyakarta: LKiS.

Haris, Syamsuddin, dkk. (2015). Position Paper: Pemilu Nasional Serentak 2019. Jakarta: Electoral Research Institute-Lembaga IImu Pengetahuan Indonesia.

Pamungkas, Sigit. (2009). Perihal Pemilu, Yogyakarta: Laboratorium Jurusan IImu Pemerintahan dan Jurusan IImu Pemerintahan Fisipol UGM.

Partono. (2010). Sistem Multi Partai, Presidensial dan Persoalan Efektivitas Pemerintah. makalah hlm. 3.

Raditya, I Gusti Ngurah. (2013). Rethinking Ketentuan Persentase sebagai syarat pencalonan Presiden dan Wakil Presiden di Indonesia. Denpasar: Universitas Udayana.

Wijaya, I Dewa Made Putra. (2014). Mengukur Derajat Demokrasi UndangUndang Nomor 42 Tahun 2008 tentang Pemilihan Umum Presiden dan Wakil Presiden. Jurnal IUS, Vol. II Nomor 6 Desember 2014, hlm. 564. 